\title{
The Effect Of SFAS 115 On Earnings Management In The Banking Industry
}

Shilo Lifschutz, (Email: shilolif@ pob.huji.ac.il), Hebrew University of Jerusalem

\begin{abstract}
This paper presents an empirical investigation into the issue of earnings management in the American banking system under SFAS 115. The study includes panel data on 88 bank holding companies (BHCs) for the years 1997-2000 on a quarterly basis resulting in 1,408 observations. As hypothesized, it was found that the motivation of bank managers to engage in gains trading is negatively related to their earnings level before tax and securities net gains.
\end{abstract}

\section{Introduction}

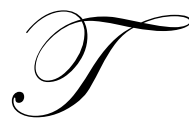

he importance of financial statements based on fair value accounting (FVA) has grown in the last decade. This is attributed to, among other things, crises in the American banking system, and in particular, the fall of savings and loan institutions (S\&L) and the loan crisis in less developed countries. In addition, the rapid growth of financial instruments and the need to improve advanced methods of risk management have forced the accounting profession to adjust to the dynamic changing economic environment and to answer the growing needs of financial report users. Financial assets based on FVA are especially important for banks because most of their assets are financial: There is a market price for some of the assets and others can be evaluated on the basis of expected discounted cash flow stream or some other acceptable model.

The Statement of Financial Accounting Standards No. 115 (SFAS 115) in 1993 dealing with securities represents an important landmark in FVA. SFAS 115 divides securities into three groups:

- $\quad$ Held-to-maturity (HTM) - Debt securities that the enterprise has the positive intent and ability to hold to maturity.

- $\quad$ Trading - Debt and equity securities purchased with the goal to sell in the near term.

- $\quad$ Available-for-sale (AFS) - Debt and equity securities not classified as either HTM or trading.

The accounting treatment and reporting for each of these groups is different: The accounting for HTM is based on the principle of historical cost (unrealized holding gains and losses are not recognized), and in the trading and AFS groups, the accounting is based on fair value (usually the market price). Unrealized holding gains and losses are recorded in income in the case of trading securities and in equity in the case of AFS.

The classification of securities as AFS creates new opportunities for gains trading. Jordan et al. (1997, p. 50) defines gains trading as "... the practice of selling securities with unrealized holding gains so that their realized holding gains increase income while securities with unrealized losses are held." The present investigation is motivated by Jordan et al. (1997), who found evidence of earnings management under SFAS 115 in the insurance industry. Jordan et al. raise doubts as to the existence of gains trading under SFAS 115 in the banking industry. According to them, AFS classification (and the potential for gains trading) affects equity volatility and the capital ratio, which are more important to banks than to insurance companies. They conclude that the adoption of SFAS $130,{ }^{1}$ and

Readers with comments or questions are encouraged to contact the author via email. 
the use of comprehensive income (thereby making the manageable item more visible) may eliminate gains trading under SFAS 115.

The purpose of this study is to examine empirically the question of earnings management under SFAS 115 in the American banking system in more recent years (1997-2000), taking into account the possible effect of SFAS 130. The panel data was based on Y9-Reports. These reports are sent to the Federal Reserve Board (FRB) by bank holding companies (BHCs) and were available from the FFIEC (Federal Financial Institution Examination Council) website. The sample includes 88 BHCs for the years 1997-2000 on a quarterly basis resulting in 1,408 bank-quarter observations.

The results of this study may have implications for standard setters and regulators. Healy et al. (1999) state that the frequency and magnitude of earnings management should help standard setters assess the extent of earnings management and whether investors are deceived by it. They add that evidence on motives and methods of earnings management help regulators allocate resources for enforcement of the standards. ${ }^{2}$

The second section of this paper presents an analysis of SFAS 115 considerations in the present and a review of the theoretical aspects of earnings management. In addition, we develop the main hypotheses. The third section describes the research design, develops the empirical model, and presents the predictions. The fourth section describes the regression results and the fifth section, provides a summary and conclusions. The final section gives suggestions for future research. ${ }^{2}$

\section{SFAS 115 and Earnings Management: Literature Review}

\subsection{The Principles of SFAS 115}

Prior to the adoption of SFAS 115, banks classified a securities portfolio into three categories: (1) a debt portfolio for investment that banks intended and were able to hold for long term, carried at amortized cost; (2) a portfolio of debt and equity securities that might be disposed of in the near future, recorded at "the lower of cost or market;" (3) a trading portfolio of debt securities actively traded, recorded at market value.

The investment securities portfolio was by far the largest portfolio and, for most banks, the trading portfolio was minor. The gradual transition to FVA, like the desire to create more symmetry in the accounting treatment between reduction and appreciation in values of securities, contributed to the issuance of SFAS 115.

SFAS 115 tried to resolve five central issues (SFAS 115, Paragraph 27):

1. Diversity in reporting created by inconsistent accounting for securities among different industries.

2. Uneven treatment created by use of "lower of cost or market" due to its recognition of reduction in value and not appreciation in value.

3. The claim that information of fair value about securities was more relevant than amortized cost information because it helped users to assess the effect of current economic events on the firm.

4. Use of historical cost made it possible for managers to manage earnings through selective sale of securities whose value rose, without the demand to recognize the concurrent loss.

5. The claim that use of "the intent of the managers" rather than "asset characteristics" regarding the decision to hold securities for the purpose of investment or for the purpose of sale was subjective and impaired comparability.

In SFAS 115, Paragraph 28, FASB claims to have succeeded in solving the first two problems and partially addressing the third topic, but admits that the last two problems remained unresolved.

SFAS 115 addresses accounting for investments in debt securities and investments in equity securities with readily determinable fair value. The standard requires the classification of each security to one of the three portfolios based on the motivation for buying the security and the intention to hold the security to maturity, to resell in the near 
future, or to sell at some undefined future time.

Investment in debt securities is classified as HTM only if the firm has the positive intent and ability to hold to maturity. A security cannot be classified as HTM if the firm intends to sell it in response to changes in market rates or prepayment risk, need for liquidity, changes of yields in alternative investments, changes in funding sources and terms, or changes in foreign currency risk. The Securities and Exchange Commission (SEC) made the classification decision of security as HTM-binding. The SEC requires firms that have sold HTM securities to reclassify the remaining HTM portfolio as AFS at fair value. This is a severe sanction because it creates a new accounting volatility in capital.

However, according to SFAS 115 (Paragraph 8), there are special instances where the bank can change its intent to hold to maturity without raising doubt as to its original intent. This applies to very specific cases such as a significant deterioration in the credit quality of a security or a change in a tax law that eliminates or reduces the taxexempt status of a security.

Trading securities are bought and held primarily to sell in the near future. The goal is to generate profit from short-term differences in market prices. As noted, these securities are reported at fair value. Unrealized holding gains and losses are included in income.

AFS securities are investments in securities that are not classified as HTM or trading. These securities are recorded at fair value but unrealized holding gains and losses are excluded from income and reported as a separate component in equity.

The approach of the FASB is unique in that it represents an attempt to deal with the claim that the fair value method involves asymmetric treatment. According to this claim, the measurement in terms of fair value of certain assets without including liabilities creates a misrepresentation of volatility in profits and does not appropriately reveal risk management practice and the overall effect on the firm. The reporting of unrealized holding gains and losses on AFS securities in equity and not as a part of the periodic income prevents volatility of accounting profits.

\subsection{Earnings Management}

Earnings management is defined by Beattie et al. $(1994,792-793)$ as follows: "a process of taking deliberate steps within the constraints of generally accepted accounting principles to bring about a desired level of reported earnings." A later definition by Healy and Wahlen $(1999,368)$ emphasizes the capital market: "Earnings management occurs when managers use judgment in financial reporting and in structuring transactions to alter financial reports to either mislead some stakeholders about the underlying economic performance of the company, or to influence contractual outcomes that depend on reported accounting numbers."

The motivation of the managers to smooth earnings stems from a number of considerations: reducing risks (Amihud \& Lev, 1981; Agrawal \& Mandelker, 1987); strengthening manager trust and reputation (Ronen \& Sadan, 1981; DeFond \& Park, 1997); maximum compensation and bonus (Lambert, 1984; Healy, 1985; Gaver et al., 1999; Holthausen et al., 1995; Guidry et al., 1999); reducing political cost by supervisors (Watts \& Zimmerman, 1978; 1990; Hagerman \& Zmijewski, 1979); preventing pressure of labor unions (Moses, 1987); meeting analysts' forecasts (Degeorge et al., 1999), and improving terms of equity offerings (Teoh et al., 1998; Rangan et al., 1998).

It is important to mention the theoretical connection between the earnings management in banks and agency theory. According to agency theory, the separation between the shareholders and managers of firms may lead to lack of identity of interests between shareholders and managers and lack of symmetry in information (Jensen \& Meckling, 1976). In the banking field, the problem of an additional conflict may exist between the regulators and the bank. Lack of symmetry in information stems from the fact that the managers know more about the profit and the risk than the regulators and that a part of the risk is not supervised. In addition, the political cost hypothesis suggests that larger banks are more exposed to political pressures from regulators because of their dominant influence on the economic system's stability. Because these banks' big profits or losses are in absolute terms, high profits attract 
much more attention from the regulators and, in turn, high costs for the banks due to regulatory intervention (Moyer, 1990).

\subsection{Using SFAS 115 Rules in Earnings Management and the Main Hypotheses}

A number of studies have shown that prior to the adoption of SFAS 115, banks smoothed income via selective sale of securities (Barth et al., 1990; Warfield \& Linsmeier, 1992). Warfield and Linsmeier (1992) explain their weak results to the possibility that the provision for loan losses is a better smoothing device.

Empirical investigation into the occurrence of earnings management in banks via the provision for loan losses has shown that managers smoothed income using the provision for loan losses (for the U.S., see Collins et al., 1995; Beatty et al., 1995; Kim \& Kross, 1998; for Denmark, see Bernard et al., 1995; for Israel, see Lifschutz, 1994; Zaken \& Parush, 1997).

Barlev $(1995,218)$ claims that different accounting treatment for different security investment categories violates neutrality in accounting and raises doubt as to the quality of accounting measurement. For instance, two businesses with an identical portfolio and with similar goals may present different results depending on managerial motivation regarding securities classification.

A number of authors argue that AFS classification creates the opportunity for earnings management by gains trading (see, for example, Munter \& Moores, 1994; Wampler \& Phillips, 1994; Powers, 1995). Ivancevich et al. (1996) demonstrate the standard numerically and show how different categories influence financial ratios: EPS, leverage ratio and current ratio. They argue that managers classify securities in order to achieve, among other things, desired financial ratios.

Earnings management through SFAS 115 has yet to be analyzed empirically in the American banking industry. The only existing study on the topic relates to the field of insurance (Jordan et al., 1997). The study of Jordan et al., which was conducted on 108 insurance companies for the year 1995, confirmed the occurrence of earnings management under SFAS 115. Two dependent variables were used: (1) the ratio of net realized gains to AFS securities and (2) the ratio of net realized gains to net unrealized gains. The independent variables were return on assets (before tax and securities net gains), leverage, and size of the company. In their study, a negative and significant coefficient was found for ROA (return on assets) in the two regressions. Leverage and size of the company were not found significant in the two regressions.

The present study extends prior research to include the banking industry and a more recent time period:

1. Industry: The incentive for gains trading in the banking industry and in the insurance industry may be different because insurers are concerned with cash reserve and liquidity and banks are more concerned with capital and the capital ratio. Jordan et al. (1997, p.51) argue, “... banks may be greatly affected by the equity volatility caused by AFS classification which may override desires to manage earnings through gains trading." In addition, investment in securities is a much more significant item in the balance sheet of insurers than of banks. Therefore, it is important to test gains trading under SFAS 115 in the banking industry.

2. Period: Prior studies relate to the years before the adoption of SFAS 115. The data used by Jordan et al. (1997) relates to only one year after adoption of the standard without a time-series analysis. Moreover, SFAS 130 became effective after 1997. This standard may have changed the earnings management behavior of banks because according to the standard, the inclusion of unrealized gains and losses on AFS securities in comprehensive income may reveal "the manageable item" and eliminate gains trading using AFS securities. Therefore, it is important to conduct a new study using cross-sectional regression on a quarterly basis across recent years. 


\section{$\underline{\text { Hypotheses }}$}

As discussed in Section 2.2, there are many incentives for earnings management. For example, earnings management may result from a manager's need to reduce employment risk (Amihud \& Lev, 1981) or to enhance his reputation (Ronen \& Sadan, 1981). A bank manager who is interested in increasing profits in order to meet a certain level of profitability can do this by gains trading, that is, by selling profitable securities from the AFS portfolio.

H1: Our first hypothesis posits that there will be a negative correlation between the profitability of a bank (before securities net gains and before tax) and gains trading.

Risk-based capital ratio is an accepted stability measure among regulators. Banks with low capital ratios are examined in a more intensive way by the supervisory authorities because of their higher risk. If regulators use capital ratios to monitor banks and their intervention incurs regulatory costs, a bank manager may act to reduce such costs by making certain adjustments. A manager will make adjustments as long as the expected reductions to regulatory or political costs exceed the adjustment costs (Moyer, 1990). Because the regulatory cost is higher for low capitalized banks, they are expected to make more adjustments.

H2: Our second hypothesis posits a negative correlation between the bank's capital ratio (before net gains) and gains trading.

According to the political cost hypothesis (discussed in Section 2.2), large banks come under more intensive examination by regulators because of their significant profits, which sometimes represent monopoly profits. Therefore, larger banks are expected to be more concerned with reporting high profits and they may adjust profits downward to reduce the higher political cost.

H3: Hypothesis 3 posits a negative correlation between bank size and gains trading.

\section{Empirical Model and Predictions}

\subsection{Sample and Data}

Eighty-eight large bank holding companies (BHCs) were examined for the years 1997 to 2000 on a quarterly basis resulting in 1,408 bank-quarter observations. The panel data is based on Y-Reports (set of financial reports) required by the FRB, which were available for the above years from the FFIEC (Federal Financial Institution Examination Council) website.

The sample of 88 BHCs was created after the elimination of: (1) BHCs lacking data for all 16 quarters and (2) BHCs not required to hold the minimal risk based capital ratio as described below:

BHCs whose total assets are over 5 billion dollars according to the FFIEC list ${ }^{3}$ :

BHCs lacking data for all 16 quarter

BHCs with no minimal risk based capital ratio:

Total BHCs in the sample:

Below we will use the term "bank" for BHC.

\subsection{Methodology, Variables Definitions, and Predictions}

Our dependent variable is similar to the one used by Jordan et al. (1997): the ratio of net realized gains on securities to total value of AFS securities. 
The independent variables represent the following:

- $\quad$ Profitability before tax and securities net gains. (H1).

- $\quad$ Capital ratio. (H2).

- $\quad$ Size of the bank. (H3).

- Macro-economic variables representing the interest rate environment.

The OLS multiple regression models are:

(1) GAINS $_{\text {it }}=\alpha_{0}+\alpha_{1} * \mathrm{ROE}_{\mathrm{it}}+\alpha_{2} * \mathrm{RBCR}_{\mathrm{it}}+\alpha_{3} * \mathrm{LNTA}_{\mathrm{it}}+\mathrm{u}_{\mathrm{it}}$

$$
\begin{aligned}
\text { GAINS }_{\text {it }} & =\beta_{0}+\beta_{1} * \mathrm{ROE}_{\text {it }}+\beta_{2} * \mathrm{RBCR}_{\mathrm{it}}+\beta_{3} * \mathrm{LNTA}_{\mathrm{it}}+\beta_{4} * \mathrm{ROELNTA}_{\mathrm{it}}+\varepsilon_{\text {it }} \\
\mathrm{GAINS}_{\mathrm{it}} & =\delta_{0}+\delta_{1} * \mathrm{ROE}_{\mathrm{it}}+\delta_{2} * \mathrm{RBCR}_{\mathrm{it}}+\delta_{3} * \mathrm{LNTA}_{\mathrm{it}}+\delta_{4} * \mathrm{ROELNTA}_{\mathrm{it}} \\
& +\delta_{5} * \mathrm{YLD}_{\mathrm{it}}+\delta_{6} * \mathrm{VOLYLD}_{\mathrm{it}}+\varphi_{\mathrm{it}} \\
\mathrm{GAINS}_{\mathrm{it}} & =\alpha_{0}+\alpha_{1} * \mathrm{ROA}_{\mathrm{it}}+\alpha_{2} * \mathrm{RBCR}_{\mathrm{it}}+\alpha_{3} * \mathrm{LNTA}_{\mathrm{it}}+\mathrm{u}_{\mathrm{it}} \\
\mathrm{GAINS}_{\mathrm{it}} & =\beta_{0}+\beta_{1} * \mathrm{ROA}_{\mathrm{it}}+\beta_{2} * \mathrm{RBCR}_{\mathrm{it}}+\beta_{3} * \mathrm{LNTA}_{\mathrm{it}}+\beta_{4} * \mathrm{ROALNTA}_{\mathrm{it}}+\varepsilon_{\mathrm{it}} \\
\mathrm{GAINS}_{\mathrm{it}} & =\delta_{0}+\delta_{1} * \mathrm{ROA}_{\mathrm{it}}+\delta_{2} * \mathrm{RBCR}_{\mathrm{it}}+\delta_{3} * \mathrm{LNTA}_{\mathrm{it}}+\delta_{4} * \mathrm{ROALNTA}_{\mathrm{it}} \\
& +\delta_{5} * \mathrm{YLD}_{\mathrm{it}}+\delta_{6} * \mathrm{VOLYLD}_{\mathrm{it}}+\varphi_{\mathrm{it}}
\end{aligned}
$$

The index i denotes the bank and the index $\mathrm{t}$ denotes the quarter.

Moyer (1990) provides a discussion regarding the distinction between discretionary (manageable) and nondiscretionary components of earnings. Fields et al. (2001) review research on accounting choice and claim that the distinction between discretionary and non-discretionary components introduces measurement errors. Barth et al. (1990), Warfield and Linsmeier (1992) and Jordan et al. (1997) treat all realized net gains as discretionary income. For simplicity, we follow their approach and assume that all realized net gains of securities are discretionary.

The dependent variable (GAINS) is the sum of realized net gains on securities (henceforth, net gains) divided by total AFS securities.

\section{The Independent Variables:}

The main independent variables for the examination of the earnings management hypothesis are provided by the following ratios:

(1) Profitability of income before tax and before net gains divided by capital (ROE) or assets (ROA). According to Hypothesis 1 , the lower this ratio, the higher the motivation of managers to engage in gains trading. Conversely, the higher the ROE or ROA, the lower the motivation for gains trading. Hence, we predict that the coefficient on ROE and ROA will be negative.

(2) Risk-Based Capital Ratio before net gains (RBCR). This ratio, which became an accepted stability measure in the banking system during the 1980s, measures the ratio between the bank's capital and its risk assets. Risk assets also include the off-balance sheet activity. Risk is measured by exposure to credit risk and assigned weights according to different counterparty categories (for instance, in the case of credit to the United States government - the weight is $0 \%$, credit to the public $-100 \%$, etc.). In recent years, there has been a demand from banks to incorporate market risks (such as interest rate risk) in the capital ratio measure. This is done by adding positions to risk assets in a standard approach or by using a model. A lower capital ratio may signal a stability problem. In this 
event, we expect the level of risk based capital ratio before net gains to have a negative effect on the motivation to engage in gains trading (see Hypothesis 2). The coefficient on RBCR is expected to be negative.

(3) $L N$ (natural log) of Total Assets (LNTA). This variable is a proxy for the size of a bank and measured by the natural $\log$ of its assets. According to the political cost hypothesis (Hypothesis 3), larger banks are expected to be more concerned with high profits and they will try to adjust profits downward. The coefficient on LNTA is expected to be negative.

(4) Interactions of Variables: ROELNTA or ROALNTA. These variables are the product of the profitability variables (ROE or ROA) and the size of the bank (LNTA).

(5) Macro-Economic Variables: We use two variables as control variables. The first is YLD, which is the average 5-year Treasury bond, yield for each quarter measured on a weekly basis. The second is VOLYLD, which is the annual volatility of YLD.

This study has a number of limitations stemming from the omission of variables such as bonuses, taxes and financial hedging, due to the unavailability of data and despite the theoretical justification of their inclusion. Likewise, it must be remembered that additional earnings management tools exist (such as provision for loan losses), and in this article we relate to the possible use of only one of them, namely securities gains trading.

\section{Empirical Results}

Table 1 presents the regression results in columns 1 to 6 . Column 1 of Table 1 shows a negative relation between ROE and GAINS. The coefficient is -0.051 and it is significant at the $1 \%$ level. Banks with a lower ROE ratio were more highly motivated to engage in gains trading. This result strengthens the claim that banks managed earnings through gains trading of securities. In column 2, we added ROELNTA to column 1 in order to test the sensitivity of larger banks to a change in ROE. The coefficient of ROELNTA is positive (0.030) and significant. This finding suggests that the larger the bank, the less sensitive it is to a change in ROE.

The negative and significant coefficients of bank size (LNTA) in columns 2,3,5 and 6 provide evidence that larger banks adjusted profits downward through gains trading of securities. This finding is consistent with the political cost hypothesis.

In order to test another accepted measure of profitability, we replaced ROE with ROA in column 4. Again we obtained a negative and very significant relation with GAINS. When we added the interaction variable (ROALNTA) in column 5, we obtained a positive coefficient.

A negative relation was obtained between the capital ratio and the gains trading variable in columns 1,2 , and 3 (significant only in columns 2 and 3). However, in columns 4 to 6 , we did not find a clear relationship. Finally, the effect of the macro-economic variables was not clear in columns 3 and 6. 
Table 1

Regression Results

\begin{tabular}{|c|c|c|c|c|c|c|}
\hline $\begin{array}{l}\text { Independent } \\
\text { variable }\end{array}$ & (1) & (2) & (3) & (4) & (5) & (6) \\
\hline \multirow[t]{2}{*}{ Intercept } & 0.011 & 0.129 & 0.137 & 0.008 & 0.159 & 0.167 \\
\hline & 0.745 & $4.858 * *$ & $4.842 * *$ & 0.604 & $6.279 * *$ & $6.108 * *$ \\
\hline \multirow[t]{2}{*}{$\mathrm{ROE}$} & -0.051 & -0.573 & -0.570 & & & \\
\hline & $-6.829 * *$ & $-5.824 * *$ & $-5.774 * *$ & & & \\
\hline \multirow[t]{2}{*}{ ROELNTA } & & 0.030 & 0.030 & & & \\
\hline & & $5.316 * *$ & $5.275^{* *}$ & & & \\
\hline \multirow[t]{2}{*}{$\mathrm{ROA}$} & & & & -1.298 & -10.210 & -10.246 \\
\hline & & & & $-14.997 * *$ & $-8.027 * *$ & $-8.032 * *$ \\
\hline \multirow[t]{2}{*}{ ROALNTA } & & & & & 0.521 & 0.524 \\
\hline & & & & & $7.027 * *$ & $7.034 * *$ \\
\hline \multirow[t]{2}{*}{ RBCR } & -0.062 & -0.068 & -0.071 & -0.001 & 0.018 & 0.015 \\
\hline & -1.836 & $-2.023 *$ & $-2.112 *$ & -0.039 & 0.584 & 0.472 \\
\hline \multirow[t]{2}{*}{ LNTA } & 0.001 & -0.006 & -0.006 & 0.001 & -0.008 & -0.008 \\
\hline & 0.925 & $-4.142 * *$ & $-4.068 * *$ & 1.493 & $-5.396 * *$ & $-5.376^{* *}$ \\
\hline \multirow[t]{2}{*}{ YLD } & & & -0.001 & & & -0.001 \\
\hline & & & -0.583 & & & -0.402 \\
\hline \multirow[t]{2}{*}{ VOLYLD } & & & -0.001 & & & -0.001 \\
\hline & & & -1.070 & & & -1.083 \\
\hline Adj. $R^{\wedge} 2$ & 0.03 & 0.05 & 0.05 & 0.14 & 0.17 & 0.17 \\
\hline F value & $17.2 * *$ & $20.2 * *$ & $13.6 * *$ & $76.8 * *$ & $71.9 * *$ & $48.1 * *$ \\
\hline
\end{tabular}

$\mathrm{t}$ values in the second line.

*significant at 0.05 level. **significant at 0.01 level.

The OLS multiple regression models are:

(1) $\quad$ GAINS $_{\text {it }}=\alpha_{0}+\alpha_{1} * \mathrm{ROE}_{\mathrm{it}}+\alpha_{2} * \mathrm{RBCR}_{\mathrm{it}}+\alpha_{3} * \mathrm{LNTA}_{\mathrm{it}}+\mathrm{u}_{\mathrm{it}}$

(2) $\quad$ GAINS $_{\text {it }}=\beta_{0}+\beta_{1} * \mathrm{ROE}_{\mathrm{it}}+\beta_{2} * \mathrm{RBCR}_{\mathrm{it}}+\beta_{3} * \mathrm{LNTA}_{\mathrm{it}}+\beta_{4} * \mathrm{ROELNTA}_{\mathrm{it}}+\varepsilon_{\mathrm{it}}$

(3) $\quad$ GAINS $_{\text {it }}=\delta_{0}+\delta_{1} * \mathrm{ROE}_{\mathrm{it}}+\delta_{2} * \mathrm{RBCR}_{\mathrm{it}}+\delta_{3} * \mathrm{LNTA}_{\mathrm{it}}+\delta_{4} * \mathrm{ROELNTA}_{\mathrm{it}}$

$$
+\delta_{5} * \mathrm{YLD}_{\mathrm{it}}+\delta_{6} * \mathrm{VOLYLD}_{\mathrm{it}}+\varphi_{\mathrm{it}}
$$

$$
\text { GAINS }_{\text {it }}=\alpha_{0}+\alpha_{1} * \mathrm{ROA}_{\mathrm{it}}+\alpha_{2} * \mathrm{RBCR}_{\mathrm{it}}+\alpha_{3} * \mathrm{LNTA}_{\mathrm{it}}+\mathrm{u}_{\mathrm{it}}
$$

$$
\text { GAINS }_{i t}=\beta_{0}+\beta_{1} * \mathrm{ROA}_{\mathrm{it}}+\beta_{2} * \mathrm{RBCR}_{\mathrm{it}}+\beta_{3} * \mathrm{LNTA}_{\mathrm{it}}+\beta_{4} * \mathrm{ROALNTA}_{\mathrm{it}}+\varepsilon_{\mathrm{it}}
$$

$$
\begin{aligned}
\text { GAINS }_{\text {it }} & =\delta_{0}+\delta_{1} * \mathrm{ROA}_{\mathrm{it}}+\delta_{2} * \mathrm{RBCR}_{\mathrm{it}}+\delta_{3} * \mathrm{LNTA}_{\mathrm{it}}+\delta_{4} * \mathrm{ROALNTA}_{\mathrm{it}} \\
& +\delta_{5} * \mathrm{YLD}_{\mathrm{it}}+\delta_{6} * \mathrm{VOLYLD}_{\mathrm{it}}+\varphi_{\mathrm{it}}
\end{aligned}
$$

Variables:

GAINS $=\underline{\text { net realized gains of securities }}$ total AFS securities

$\mathrm{ROE}=$ profitability to capital of income before tax and before net gains

$\mathrm{ROA}=$ profitability to assets of income before tax and before net gains .

ROELNTA $=$ the interaction of ROE and LNTA.

ROALNTA $=$ the interaction of ROA and LNTA.

$\mathrm{RBCR}=$ risk based capital ratio before net gains.

$\mathrm{LNTA}=\ln$ of total assets.

YLD $=5$ year $\mathrm{T}$ Bonds yield.

VOLYLD = volatility of YLD. 


\section{Summary and Conclusions}

This paper examines the issue of earnings management in the American banking system under SFAS 115. According to the study's main hypothesis, the motivation of bank managers to engage in gains trading is negatively related to the profitability level before tax and securities net gains. The findings of this study support the hypothesis that (in 1997-2000) banks took advantage of the flexibility in SFAS 115 and managed earnings through gains trading of securities.

The results of the study sharpen the question whether FVA should now be made applicable to all securities. The existing accounting treatment based on SFAS 115 provides managers with another tool to manage earnings. This proves that the accounting standards influence certain decisions of managers and the neutrality of accounting is impaired.

A full transfer to FVA for all types of securities may constitute an important step in attempting to reduce the occurrence of earnings management. In this context, it should be recalled that such a step would have a price, namely, increased accounting volatility in the income statement. However, the adoption of SFAS 133, calling for recording all derivatives on the balance sheet and at fair value also creates a new accounting volatility in the income statement.

SFAS 133 and the gradual move of the accounting standard setting bodies to FVA may indicate that the time has come to modify SFAS 115: reporting all securities at fair value and including unrealized changes in fair value in earnings. This may resolve the problems of accounting based on managerial intent and the occurrence of gains trading and will increase the relevance and reliability of accounting information.

\section{Suggestions for Future Research}

This study can be extended in two major areas. The first relates to correlated omitted variables. Due to the unavailability of data, variables such as bonuses, taxes and financial hedging were not included despite the theoretical justification of their inclusion. These variables should be tested when adequate time-series data become available. The second extension results from the multiple method choice of managers. It should be noted that additional earnings management tools could be used by managers such as the provision for loan losses. In this paper, we relate to the possible use of only one of them, namely, securities gains trading. Future research should examine other earnings management tools and test them as substitutes for, or complementary to the measure used here.

\section{Endnotes}

(1) SFAS 130: "Reporting Comprehensive Income" became effective after 1997. According to SFAS 130, unrealized gains and losses on AFS securities are included in comprehensive income. This means that comprehensive income is the same whether AFS securities are held or sold. Hirst and Hopkins (1998) found evidence that comprehensive income enhances analysts' detection of earning management relative to footnote disclosure.

(2) The SEC has set up an earnings management task force in order to identify firms that manage earnings and is expected to require restatement of earnings and to enforce new disclosure (Healy et al., 1999).

(3) Because securities activity is more significant in large banks, we did not include banks with total assets of less than 5 billion dollars.

\section{References}

1. Agrawal, A., and G. N. Mandelker, "Managerial Incentives and Financing Decisions", Journal of Finance 42 (September), pp. 823-837, 1987.

2. Amihud, Y., and B. Lev, "Risk Reduction as Managerial Motive for Conglomerate Mergers", The Bell Journal of Economics 12 (Autumn), pp. 605-617, 1981.

3. Barlev, B., Financial Accounting Theory and Applications. Jerusalem: Magnes, 1995. (Hebrew). 
4. Barth, M., W. Beaver, and M. Wolfson, "Components of Bank Earnings and the Structure of Bank Share Prices", Financial Analysts Journal (May/ June), pp. 53-60, 1990.

5. Beattie, V., S. Brown, D. Ewers, J. Brian, S. Manson, D. Thomas, and M. Turner, "Extraordinary Items and Income Smoothing: A Positive Accounting Approach", Journal of Business Finance and Accounting 21, No. 6, pp. 791-811, 1994.

6. Beatty A., S. Chamberlain and J. Magliolo, "Managing Financial Reports of Commercial Banks: The Influence of Taxes, Regulatory Capital and Earnings", Journal of Accounting Research 3, No. 2, pp. 231-261, 1995.

7. Bernard V. L., R. C. Merton, and K. G. Palepu, "Mark To Market Accounting for Banks and Thrifts: Lessons from The Danish Experience”, Journal of Accounting Research 33, No. 1, pp. 1-32, 1995.

8. Collins, J. H., D. A. Shackelford, and J. M. Wahlen, "Bank Differences in the Coordination of Regulatory Capital Earnings and Taxes", Journal of Accounting Research 33, No. 2, pp. 263-291, 1995.

9. Degeorge, F., J. Patel, and R. Zeckhauser, "Earnings Management to Exceed Thresholds", Journal of Business 72, pp. 1-33, 1999.

10. DeFond, M., and C. Park, "Smoothing Income in Anticipation of Future Earnings", Journal of Accounting and Economics 23, pp. 115-139, 1997.

11. Fields, T. D., T. Z. Lys, and L. Vincent, "Empirical Research on Accounting Choice", Journal of Accounting and Economics 31, pp. 255-307, 2001.

12. Gaver, J., K. Gaver, and J. Austin, "Additional Evidence on Banks Plans and Income Management", Journal of Accounting and Economics 26, pp. 113-142, 1999.

13. Guidry, F., A. Leone, and S. Rock, "Earning Based Bonus Plans and Earnings Management by Business-Unit Managers", Journal of Accounting and Economics 26, pp. 113-142, 1999.

14. Hagerman, R. L, and M. E. Zmijewski, "Some Economic Determinants of Accounting Policy Choice", Journal of Accounting and Economics 1, pp. 141-161, 1979.

15. Healy, P. M., "The Effects of Bonus Schemes on Accounting Decisions", Journal of Accounting and Economics 7, pp. 85-107, 1985.

16. Healy, P.M., and J. M. Wahlen, "A Review of the Earnings Management Literature and its Implications for Standard Setting”, Accounting Horizons 13 No. 4, pp. 365-383, 1999.

17. Hirst, D. E., and P.E. Hopkins, "Comprehensive Income Reporting and Analysts' Valuation Judgments", Journal of Accounting Research (Supplement), pp. 47-75, 1998.

18. Holthausen, R., D. Larcker, and R. Sloan, "Annual Bonus Schemes and Manipulation of Earnings", Journal of Accounting and Economics 19, pp. 29-74, 1995.

19. Ivancevich, D. M., A. F. Cocco, and S. H. Ivancevich, "The Effect of SFAS No. 115 on Financial Statement Analysis", The Ohio CPA Journal (December), pp. 32-37, 1996.

20. Jensen, M. C., and W. H. Meckling, "The Theory of the Firm: Managerial Incentives, Agency Costs and Capital Structure”, Journal of Financial Economics 3, pp. 305-360, 1976.

21. Jordan C. E., S. J Clark and W. R Smith, "Earnings Management Under SFAS No. 115: Evidence from the Insurance Industry", Journal of Applied Business Research 14, No. 1, pp. 49-56, 1997.

22. Kim M.S., and W. Kross, "The Impact of the 1989 Change in Bank Capital Standards on Loan Loss Provisions and Loan Write- Offs", Journal of Accounting and Economics 25, pp. 69-99, 1998.

23. Lambert, R. A., "Income Smoothing as Rational Equilibrium Behavior", The Accounting Review (October), pp. 604-618, 1984.

24. Lifschutz S., The Effect of Risk Factors and Income Smoothing on the Loan Loss Provisions of the Israeli Banks. The Joseph Kasierer Institute for Research in Accounting: Tel Aviv University, 1994. (Hebrew).

25. Moses, O. D., "Income Smoothing and Incentives: Empirical Tests Using Accounting Changes", The Accounting Review (April), pp. 358-372, 1987.

26. Moyer, S.E., "Capital Adequacy Ratio Regulations and Accounting Choices in Commercial Banks", Journal of Accounting and Economics 13, pp. 123-154, 1990.

27. Munter, P., and T, Moores, “A New look at Market Value Accounting”, Management Accounting 75, No. 9 (March), pp. 41-45, 1994.

28. Powers, O. S., "Fair Values: A Change in Investment Accounting", National Public Accounting 40, No. 1, (Jan) pp. 32-36, 1995. 
29. Rangan, S., "Earnings Management and the Performance of Seasoned Equity Offerings", Journal of Financial Economics 50, pp. 101-122, 1998.

30. Ronen, J., and S. Sadan, Smoothing Income Numbers: Objectives, Means and Implications. Reading, MA: Addison- Wesley, 1981.

31. SFAS 115, Accounting for Certain Investments in Debt and Equity Securities, 1993.

32. SFAS 130, Reporting Comprehensive Income, 1997.

33. SFAS 133, Accounting for Derivative Instruments and Hedging Activities, 1998.

34. Teoh, S. H., I. Welch and T. J. Wong, "Earnings Management and the Underperformance of Seasoned Equity Offerings", Journal of Financial Economics 50, pp. 63-99, 1998.

35. Wampler, B. M., and T. J. Phillips, " A Case of Fair Value Accounting for Debt Securities”, Management Accounting 75, No. 9 (March), pp. 46-49, 1994.

36. Warfield, T. D., and T. J. Linsmeier, "Tax Planning, Earnings Management and the Differential Information of Bank Earnings Components”, The Accounting Review 67 No. 3, (July), pp. 546-582, 1992.

37. Watts, R. L., and J.C. Zimmerman, “ Towards a Positive Theory of the Determination of Accounting Standards", The Accounting Review (January), pp. 112-134, 1978.

38. Watts, R. L., and J.C. Zimmerman, "Positive Accounting Theory: A Ten Year Perspective", The Accounting Review, (January), pp. 131-156, 1990.

39. Zaken, D., and J. Parush, "Credit Risk in the Israeli Banks: Measurement Methods and Observations, 1992-1995”, Banking Review 13 (December), pp. 97-117, 1997. (Hebrew).

\section{Acknowledgements}

This paper is based on part of my Ph.D. dissertation. I thank my dissertation committee, B. Barlev (chair), E. Kandel, and Z. Wiener for valuable comments and suggestions. I also thank R. Clute, D. Fried, E. Elyasiani, S. Ryan, and two anonymous referees for their helpful comments on earlier version of this article. 
Notes 